\title{
Nursing care for women with pre-eclampsia and/or eclampsia: integrative review
}

\author{
Assistência de enfermagem a mulheres com pré-eclâmpsia e/ou eclâmpsia: revisão integrativa \\ Asistencia de enfermería a mujeres con preeclampsia y/o eclampsia: revisión integradora
}

Maria Beatriz Guimarães Ferreira', Caroline Freitas Silveira², Sueli Riul da Silva ${ }^{3}$, Delvane José de Souza ${ }^{3}$, Mariana Torreglosa Ruiz ${ }^{3}$

How to cite this article:

Ferreira MBG, Silveira CF, Silva SR, Souza DJ, Ruiz MT. Nursing care for women with pre-eclampsia and/or eclampsia: integrative review. Rev Esc Enferm USP. 2016;50(2):320-330. DOI: http://dx.doi.org/10.1590/S0080-623420160000200020

${ }^{1}$ Universidade de São Paulo, Escola de Enfermagem de Ribeirão Preto, Programa de Pós-Graduação em Enfermagem Fundamental, Ribeirão Preto, SP, Brazil.

${ }^{2}$ Faculdade de Talentos Humanos, Curso de Graduação em Enfermagem, Uberaba, MG, Brazil.

${ }^{3}$ Universidade Federal do Triângulo Mineiro, Departamento de Enfermagem na Assistência Hospitalar, Uberaba, MG, Brazil.

\begin{abstract}
Objective: To analyze the available evidence in the literature on nursing care for women with pre-eclampsia and/or eclampsia. Methods: Integrative review searching for primary studies in the databases PubMed, CINAHL, LILACS and SciELO. Results: The sample size consisted of 17 primary studies published between January 2000 and December 2014, grouped into four categories: standardizing blood pressure measurement technique; training with simulation; instruments for standardization of care and quality of care The main nursing actions were: physical examination, early detection of signs of pre-eclampsia/eclampsia, monitoring of laboratory tests, fetal assessment, qualification and training of professionals. We identified the need for standardization of care from instruments, protocols and blood pressure measurement technique, early identification and treatment of hypertensive crisis through institutional protocols and review of cases and work processes. Conclusion: Women with pre-eclampsia and/or eclampsia require specific nursing care, which must be guided by care protocols based on scientific evidence.
\end{abstract}

\section{DESCRIPTORS}

Pre-eclampsia; Eclampsia; Nursing Care; Obstetric Nursing; Review. 


\section{INTRODUCTION}

Data from the World Health Organization (WHO) indicate that in every day of 2010, 800 women died from pregnancy or childbirth ${ }^{(1)}$. Hypertensive disorders are the second leading cause of maternal deaths, being only behind bleeding, accounting for about $14 \%$ of all maternal deaths in the world and reaching rates of up to $22 \%$ in Latin America ${ }^{(2)}$. It is also noteworthy that about $10 \%$ of all pregnancies in the world occur with some kind of hypertensive syndrome, classified as pre-eclampsia, eclampsia, gestational hypertension and chronic hypertension ${ }^{(3)}$.

According to 2011 data, from the Informatics Department of the Unified Health System (DATASUS), hypertensive disorders caused 325 deaths, representing $20 \%$ of the events of maternal deaths and $56 \%$ of these occurred during pregnancy ${ }^{(4)}$.

Pre-eclampsia is a disorder that can occur after the twentieth week of pregnancy, during childbirth and up to 48 hours postpartum. It affects about $5-8 \%$ of all pregnancies and is a condition that rapidly evolves, characterized by increased tension in blood pressure (BP) and the presence of proteinuria. Some signs may be indicative of this condition, such as edema - mainly on the face, around the eyes and hands; accelerated weight gain; nausea and/or vomiting; pain in the epigastric region that radiates to the upper limbs; headache and visual disturbances (blurred vision and/or cloudy); hyperreflexia, tachypnea and anxiety. However, the disease often progresses silently, that is, without indicative signals ${ }^{(5)}$.

Hypertension can be characterized by pressure values equal to or higher than $140 / 90 \mathrm{mmHg}$, when we do not know the individual baseline values, after at least two measurements under ideal conditions and at different times, at a minimum interval of at least six hours among the measures. However, if previous pressure values are known, one should consider as hypertensive a pregnant woman who presents increase of $15 \mathrm{mmHg}$ in diastolic blood pressure (DBP) and/or $30 \mathrm{mmHg}$ in systolic blood pressure $(\mathrm{SBP})^{(5)}$.

Proteinuria is characterized by the loss of protein in the urine and indicates that, in these cases, there is kidney damage. For its evaluation, it is necessary to make the collection of urine in 24 hours, to estimate the total loss. Pre-eclampsia is diagnosed when $2+/$ value $\geq 0.3 \mathrm{~g}$ or more protein in the 24 -hour urine associated with increased blood pressure ${ }^{(5)}$.

Eclampsia is distinguished by the presence of seizures in women whose pregnancy was complicated because of pre-eclampsia, excluding other differential diagnoses, such as epilepsy, meningitis, sepsis, among others ${ }^{(6)}$.

It must be noted that the WHO recommends the use of care protocols, as well as the prevention and treatment of these conditions with magnesium sulfate ${ }^{(5)}$. The use of the sulfate associated with the quality of care reduces by $50 \%$ the risk of mortality from pre-eclampsia or eclampsia ${ }^{(7)}$.
Given the high mortality rate caused by these conditions, as well as the high rate of unfavorable outcomes, it is essential to provide quality of nursing care based on the best scientific evidence.

It is understood that care guided by findings generated from rigorous scientific method consists of gold standard in health care ${ }^{(8)}$. This approach can improve outcomes for patients, provide higher quality of care, minimize costs due to the reduction of morbidity and mortality and iatrogenic, and promote safety and reliability standards to health organizations ${ }^{(9)}$.

The relevance of this research is the synthesis of knowledge on nursing interventions for women with pre-eclampsia and/or eclampsia, which allows the nurse better decision-making in health care, with a view to a reasoned plan of care in the incorporation of research to practical results. Thus, this study aimed to analyze the available evidence in the literature on the topic: nursing care for women with pre-eclampsia and/or eclampsia.

\section{METHOD}

The integrative review was chosen as the method to achieve the objective of the study, which was conducted in the following steps: preparation of the research question; sampling or literature searching for primary studies; data extraction; assessment of the primary studies included in the review; analysis and synthesis of the results of the review and presentation of the review ${ }^{(10)}$.

The guiding question of the integrative review was: What is the scientific evidence available in the literature about nursing care to women with pre-eclampsia and/or eclampsia?

The search for primary studies was performed through controlled descriptors, such as Medical Subject Headings, using the terms Eclampsia, Pre-Eclampsia, Nursing Care, Obstetric Nursing and Nursing; the CINAHL Headings, with Eclampsia, Pre-Eclampsia, Nursing Care, Nursing and Obstetric Nursing; and Descriptors in Health Sciences with Pre-eclampsia, Eclampsia, Nursing Care, Obstetric and Nursing. We conducted searches in the databases: US National Library of Medicine National Institutes of Health (PubMed), Cumulative Index to Nursing and Allied Health Literature (CINAHL), Latin American and Caribbean Health Sciences (LILACS) and SciELO (Scientific Electronic Library Online). The choice of databases was due to the number of indexed studies of health area, databases that include primary studies, as well as topics related to nursing. The descriptors were combined in different ways with the aim of expanding the search for studies. It is noteworthy that the terminological variations in different languages, as well as the synonyms were used to perform a high sensitive search with the use of Boolean operators AND for simultaneous occurrence of topics, and OR for the occurrence of one or the other topic. The search strategy which allowed the identification of primary studies that were included in the review are shown in Chart 1. 
Chart 1 - Search strategy conducted that enabled the identification of the primary studies in the integrative review - Uberaba, MG, Brazil, 2015.

\begin{tabular}{|c|c|c|c|c|}
\hline Databases & & Search str & tegy & \\
\hline PubMed & $\begin{array}{l}\text { Pre eclampsia and } \\
\text { eclampsia and nursing care } \\
\text { and obstetric nursing }\end{array}$ & $\begin{array}{l}\text { Pre eclampsia and } \\
\text { eclampsia and nursing } \\
\text { care and obstetric } \\
\text { nursing and nursing }\end{array}$ & & \\
\hline Number of studies & 06 & 02 & & \\
\hline LILACS & $\begin{array}{l}\text { Pre-eclampsia and nursing } \\
\text { care }\end{array}$ & $\begin{array}{c}\text { Pre-eclampsia and } \\
\text { nursing }\end{array}$ & Eclampsia and nursing care & \\
\hline Number of studies & 02 & 01 & 01 & \\
\hline CINAHL & $\begin{array}{l}\text { Pre-eclampsia and nursing } \\
\text { care }\end{array}$ & $\begin{array}{l}\text { Pre-eclampsia and } \\
\text { obstetrical nursing }\end{array}$ & Pre-eclampsia and nursing & $\begin{array}{c}\text { Eclampsia e } \\
\text { nursing }\end{array}$ \\
\hline Number of studies & 01 & 01 & 02 & 01 \\
\hline SciELO & Pre-eclampsia and nursing & & & \\
\hline Number of studies & 01 & & & \\
\hline
\end{tabular}

The search for primary studies was conducted in the databases on April $7^{\text {th }}, 2015$, by two nurse reviewers independently, one with master's degree and the other with a PhD. The search result with eligible primary studies and reasons for exclusion are described in Figure 1.

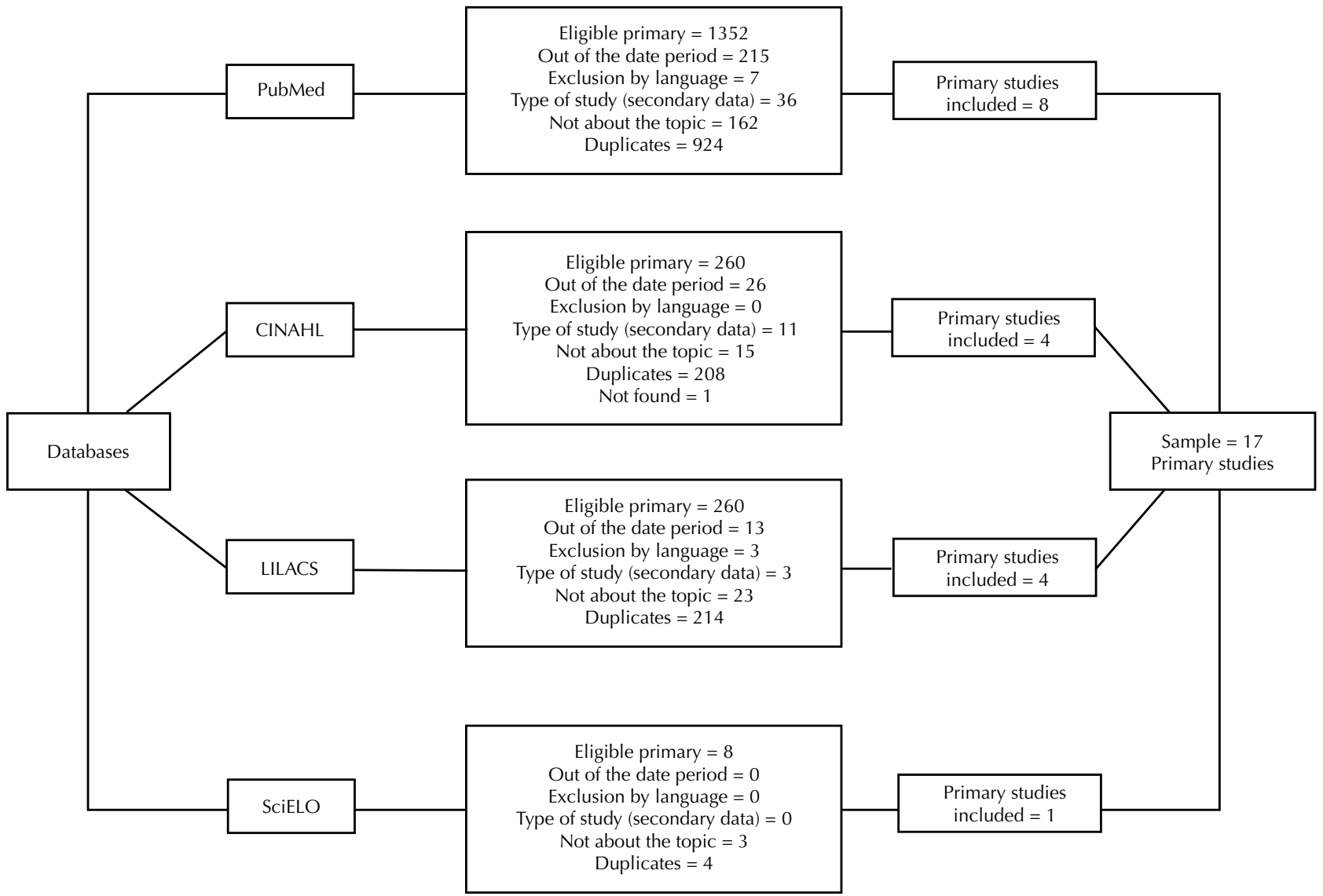

Figure 1 - Flowchart of the selection of the primary included studies and reasons for exclusion.

It is noteworthy that during the selection of studies in CINAHL database, one study, entitled "An obstetric case study on Mrs. AA with eclampsia", indexed in the West African Journal of Nursing, in 2002, was initially included so it could be submitted to reading in an attempt to determine whether or not met the inclusion criteria of this review. However, the study was not found, even after attempts through commuting and at the Cooperative Service for Document Access - SCAD, due to its unavailability, the study was excluded.

Studies describing the nursing care provided to women with pre-eclampsia and/or eclampsia, published between 
January 2000 to December 2014 and in Portuguese, Spanish and English were the criteria for inclusion of primary studies defined for the integrative review, while exclusion criteria were: editorial, letter, narrative review of the literature/ traditional review and revision methods.

We conducted title and abstract screening, according to the eligible primary studies and based in the integrative review selection criteria, 17 studies were included, which were read in full exhaustively, eight belonging to PubMed database, four from CINAHL, four from LILACS and one from SciELO.

To extract data from the selected primary studies, we used a data collection instrument, which was submitted to face and content validation, consisting of identification of the study; main institution of the study; type of journal; methodological characteristics and critical appraisal of the methodological rigor of the study ${ }^{(11)}$.

The evaluation of the types of studies have been made based on the concepts of scientific methodology of schol$\operatorname{ars}^{(12)}$, which classify studies in quantitative and qualitative methodological approaches. The analysis of the results was conducted descriptively, presenting a summary of each study included in the integrative review.

\section{RESULTS}

Out of the 17 primary studies included in the review, 15 were published in English and two in Portuguese. There was diversity in relation to journals, eight were nursing specific, two journals had more than one study - Nursing and Simulation in Healthcare $(\mathrm{n}=2)$, and only two publications were made in Brazilian journals - one in the Escola Anna Nery Revista de Enfermagem and one in the Revista LatinoAmericana de Enfermagem.

The primary studies included were classified into four thematic categories: standardizing blood pressure measurement technique (category 1); training with simulation to act against pre-eclampsia and/or eclampsia conditions (category 2); instruments for standardization of care (category 3 ) and quality of care (category 4 ). Chart 2 shows the general characterization of the primary studies. Studies one to three were grouped into the first category; the fourth to seventh study were included in the second category; eighth and ninth studies included in the third category and studies from ten to seventeen make up the fourth category.

Chart 2 - Characterization of included studies (title, country and year of publication, objectives, study design, number of participants, interventions and outcomes) - Uberaba, MG, Brazil, 2015.

\begin{tabular}{|c|c|c|c|c|c|}
\hline Title & Country/Year & Objectives & $\begin{array}{l}\text { Study design/number } \\
\text { of participants }\end{array}$ & Interventions & Outcomes \\
\hline $\begin{array}{l}\text { 1. Cuff width influence } \\
\text { on blood pressure } \\
\text { measurement during } \\
\text { the pregnant-puerperal } \\
\text { cycle(13) }\end{array}$ & $\begin{array}{l}\text { Brazil } \\
2002\end{array}$ & $\begin{array}{l}\text { To compare pressure } \\
\text { values between } \\
\text { measurements with } \\
\text { the appropriate arm } \\
\text { circumference and } \\
\text { conventional cuff }(12 \mathrm{~cm})\end{array}$ & $\begin{array}{c}\text { Quantitative } \\
\text { study, prospective } \\
\text { follow-up type/ } 104 \\
\text { pregnant women }\end{array}$ & $\begin{array}{c}\text { BP measurement } \\
\text { with conventional } \\
\text { cuff } \\
\text { and appropriate } \\
\text { to AC }\end{array}$ & $\begin{array}{l}\text { Underestimated } \\
\text { pressure value } \\
\text { when measured } \\
\text { with conventional } \\
\text { cuff }\end{array}$ \\
\hline $\begin{array}{l}\text { 2. Time Poor: Rushing } \\
\text { Decreases the Accuracy } \\
\text { and Reliability of } \\
\text { Blood Pressure } \\
\text { Measurement } \\
\text { Technique in } \\
\text { Pregnancy(14) }\end{array}$ & $\begin{array}{l}\text { Australia } \\
2006\end{array}$ & $\begin{array}{l}\text { To compare two BP } \\
\text { scouting measures with } \\
\text { quickly mercury release } \\
\text { ( } \geq 5 \mathrm{mmHg} \text { ) indicated by } \\
\text { guideline }(\leq 2 \mathrm{mmHg})\end{array}$ & $\begin{array}{l}\text { Observational } \\
\text { study/ } 98 \text { patients }\end{array}$ & $\begin{array}{c}\text { BP measurement } \\
\text { with different } \\
\text { speeds of descent } \\
\text { of the mercury } \\
\text { column }\end{array}$ & $\begin{array}{l}\text { The rapid deflation } \\
\text { of the mercury } \\
\text { underestimates BP }\end{array}$ \\
\hline $\begin{array}{l}\text { 3. Improving the } \\
\text { Outcomes of } \\
\text { Women With Severe } \\
\text { Preeclampsia: } \\
\text { Exploring Innovations } \\
\text { Used by an Inter- } \\
\text { Professional Team } \\
\text { at a Community } \\
\text { Hospital(15) }\end{array}$ & $\begin{array}{l}\text { The United } \\
\text { States of } \\
\text { America } \\
2014\end{array}$ & $\begin{array}{l}\text { To report the experience } \\
\text { of an intervention program } \\
\text { to reduce maternal } \\
\text { mortality }\end{array}$ & Case report & - & $\begin{array}{l}\text { Need for better } \\
\text { monitoring } \\
\text { of cases and } \\
\text { management care }\end{array}$ \\
\hline $\begin{array}{l}\text { 4. Preeclampsia in } \\
\text { the delivery suite: a } \\
\text { simulation scenario(16) }\end{array}$ & $\begin{array}{c}\text { Australia } \\
2013\end{array}$ & $\begin{array}{l}\text { To describe pre eclampsia } \\
\text { frame care simulation and } \\
\text { eclampsia in the delivery } \\
\text { room }\end{array}$ & Case report & - & $\begin{array}{l}\text { Care in pre } \\
\text { eclampsia and } \\
\text { eclampsia }\end{array}$ \\
\hline $\begin{array}{l}\text { 5. Hospital, simulation } \\
\text { center, and teamwork } \\
\text { training for eclampsia } \\
\text { management: a } \\
\text { randomized controlled } \\
\text { trial(17) }\end{array}$ & $\begin{array}{l}\text { United } \\
\text { Kingdom } \\
2008\end{array}$ & $\begin{array}{l}\text { To compare the } \\
\text { effectiveness of training } \\
\text { assistance to eclampsia } \\
\text { with and without the } \\
\text { teamwork theory }\end{array}$ & $\begin{array}{l}\text { Randomized } \\
\text { controlled trial/144 } \\
\text { professionals ( } 96 \\
\text { midwives and } 48 \\
\text { obstetricians) }\end{array}$ & $\begin{array}{l}\text { Training with the } \\
\text { team labor theory }\end{array}$ & $\begin{array}{l}\text { Reduction in } \\
\text { the mean time } \\
\text { to perform the } \\
\text { techniques in the } \\
\text { management of } \\
\text { eclampsia and } \\
\text { improvement in } \\
\text { care with use of } \\
\text { teamwork theory }\end{array}$ \\
\hline
\end{tabular}


...continuation

\begin{tabular}{|c|c|c|c|c|c|}
\hline Title & Country/Year & Objectives & $\begin{array}{c}\text { Study design/number } \\
\text { of participants }\end{array}$ & Interventions & Outcomes \\
\hline $\begin{array}{l}\text { 6. Prospective } \\
\text { Randomized Trial of } \\
\text { Simulation Versus } \\
\text { Didactic Teaching } \\
\text { for Obstetrical } \\
\text { Emergencies }^{(18)}\end{array}$ & $\begin{array}{l}\text { The United } \\
\text { States of } \\
\text { America } \\
2010\end{array}$ & $\begin{array}{l}\text { To compare results of } \\
\text { simulated training and } \\
\text { theoretic training } \\
\text { to deal with emergencies } \\
\text { in the delivery room }\end{array}$ & $\begin{array}{l}\text { A prospective } \\
\text { cohort study/ } 32 \\
\text { Professionals }\end{array}$ & Simulated training & $\begin{array}{l}\text { Best professional } \\
\text { performance in } \\
\text { the group that } \\
\text { performed the } \\
\text { simulated training }\end{array}$ \\
\hline $\begin{array}{l}\text { 7. Simulation Enhances } \\
\text { Self-Efficacy in the } \\
\text { Management of } \\
\text { Preeclampsia and } \\
\text { Eclampsia in Obstetrical } \\
\text { Staff Nurses }^{(19)}\end{array}$ & $\begin{array}{l}\text { The United } \\
\text { States of } \\
\text { America } \\
2013\end{array}$ & $\begin{array}{l}\text { To assess whether training } \\
\text { with realistic simulation } \\
\text { is an effective strategy in } \\
\text { the training of obstetrician } \\
\text { nurses caring for women } \\
\text { with pre-eclampsia and/or } \\
\text { eclampsia }\end{array}$ & $\begin{array}{l}\text { Quasi-experimental } \\
\text { study/49 nurses }\end{array}$ & $\begin{array}{c}\text { Training } \\
\text { with realistic } \\
\text { simulation }\end{array}$ & $\begin{array}{l}\text { Realistic training } \\
\text { enabled the early } \\
\text { identification } \\
\text { and adoption } \\
\text { of appropriate } \\
\text { nursing behaviors } \\
\text { in cases of pre- } \\
\text { eclampsia and } \\
\text { eclampsia }\end{array}$ \\
\hline $\begin{array}{l}\text { 8. Development } \\
\text { and testing of the } \\
\text { Preeclampsia Prenatal } \\
\text { Symptom-Monitoring } \\
\text { Checklist (PPMSC) }(20)\end{array}$ & $\begin{array}{l}\text { The United } \\
\text { States of } \\
\text { America } \\
2014\end{array}$ & $\begin{array}{l}\text { To refine psychometric } \\
\text { properties of an } \\
\text { instrument to assess } \\
\text { symptoms }\end{array}$ & $\begin{array}{l}\text { Methodological } \\
\text { study/100 } \\
\text { postpartum women } \\
\text { with pre eclampsia }\end{array}$ & - & $\begin{array}{l}\text { The use of the } \\
\text { scale was able to } \\
\text { identify symptoms, } \\
\text { the progression } \\
\text { and onset of } \\
\text { complications }\end{array}$ \\
\hline $\begin{array}{l}\text { 9. Monitoring Severe } \\
\text { Pre-Eclampsia and } \\
\text { Eclampsia Treatment } \\
\text { in Resource Poor } \\
\text { Countries: Skilled Birth } \\
\text { Attendant Perception } \\
\text { of a New Treatment } \\
\text { and Monitoring Chart } \\
\text { (LIVKAN Chart)(21) }\end{array}$ & $\begin{array}{l}\text { United } \\
\text { Kingdom } \\
2012\end{array}$ & $\begin{array}{c}\text { To develop a chart to } \\
\text { track the care of pregnant } \\
\text { women with pre-eclampsia } \\
\text { and eclampsia }\end{array}$ & $\begin{array}{l}\text { Methodological } \\
\text { study/118 } \\
\text { participants } \\
\text { (midwives and } \\
\text { physicians) }\end{array}$ & - & $\begin{array}{l}\text { The graphics } \\
\text { shows to be useful } \\
\text { to provide better } \\
\text { quality service } \\
\text { and good quality } \\
\text { documentation }\end{array}$ \\
\hline $\begin{array}{l}\text { 10. Late-onset } \\
\text { postpartum } \\
\text { preeclampsia: a case } \\
\text { study(22) }\end{array}$ & $\begin{array}{l}\text { The United } \\
\text { States of } \\
\text { America } \\
2014 \\
\text { Not } \\
\text { described } \\
2002\end{array}$ & $\begin{array}{l}\text { To describe a case of } \\
\text { late-onset postpartum pre- } \\
\text { eclampsia }\end{array}$ & $\begin{array}{l}\text { Case study/ } 01 \text { case } \\
\text { report }\end{array}$ & - & $\begin{array}{l}\text { Prophylaxis of } \\
\text { seizures with } \\
\text { the use of } \\
\text { magnesium sulfate }\end{array}$ \\
\hline 11. Eclampsia(23) & $\begin{array}{l}\text { Not } \\
\text { described } \\
2002\end{array}$ & $\begin{array}{l}\text { To describe a case of } \\
\text { eclampsia in pregnancy }\end{array}$ & $\begin{array}{c}\text { Case study / } 01 \text { case } \\
\text { report }\end{array}$ & - & $\begin{array}{l}\text { Care in case of } \\
\text { eclampsia }\end{array}$ \\
\hline $\begin{array}{l}\text { 12. The Critically III } \\
\text { Obstetric Patient(24) }\end{array}$ & $\begin{array}{l}\text { The United } \\
\text { States of } \\
\text { America } \\
2005\end{array}$ & $\begin{array}{l}\text { To describe a case of } \\
\text { pre-eclampsia in the } \\
\text { puerperium }\end{array}$ & $\begin{array}{l}\text { Case study/ } 01 \text { case } \\
\text { report }\end{array}$ & - & $\begin{array}{l}\text { Knowledge of the } \\
\text { pathophysiology } \\
\text { of pre-eclampsia } \\
\text { contributes } \\
\text { to nurse's } \\
\text { performance }\end{array}$ \\
\hline $\begin{array}{l}\text { 13. Emergency care of } \\
\text { postpartum patients } \\
\text { with preeclampsia and } \\
\text { eclampsia(25) }\end{array}$ & $\begin{array}{l}\text { The United } \\
\text { States of } \\
\text { America } \\
2006\end{array}$ & $\begin{array}{l}\text { To describe a case } \\
\text { of eclampsia in the } \\
\text { puerperium }\end{array}$ & $\begin{array}{l}\text { Case study/ } 01 \text { case } \\
\text { report }\end{array}$ & - & $\begin{array}{l}\text { Knowledge } \\
\text { of signs and } \\
\text { symptoms of } \\
\text { eclampsia and use } \\
\text { of care protocols } \\
\text { are needed }\end{array}$ \\
\hline $\begin{array}{l}\text { 14. Court case. } \\
\text { Delivering the } \\
\text { verdict(26) }\end{array}$ & $\begin{array}{l}\text { The United } \\
\text { States of } \\
\text { America } \\
2003\end{array}$ & $\begin{array}{l}\text { To describe a clinical case } \\
\text { of pre eclampsia in a trial }\end{array}$ & $\begin{array}{l}\text { Case study / } 01 \text { case } \\
\text { report }\end{array}$ & - & $\begin{array}{l}\text { Care and legal } \\
\text { aspects of care }\end{array}$ \\
\hline $\begin{array}{l}\text { 15. Substandard care in } \\
\text { maternal mortality due } \\
\text { to hypertensive disease } \\
\text { in pregnancy in the } \\
\text { Netherlands(27) }\end{array}$ & $\begin{array}{l}\text { Netherlands } \\
2008\end{array}$ & $\begin{array}{l}\text { To assess quality of care in } \\
\text { cases of maternal death by } \\
\text { hypertensive disorders }\end{array}$ & $\begin{array}{l}\text { A retrospective } \\
\text { descriptive study } \\
/ 135 \text { cases of } \\
\text { maternal deaths }\end{array}$ & - & Low quality care \\
\hline
\end{tabular}

continued... 
...continuation

\begin{tabular}{|c|c|c|c|c|c|}
\hline Title & Country/Year & Objectives & $\begin{array}{l}\text { Study design/number } \\
\text { of participants }\end{array}$ & Interventions & Outcomes \\
\hline $\begin{array}{l}\text { 16. Assistência de } \\
\text { enfermagem na opinião } \\
\text { das mulheres com } \\
\text { pré-eclâmpsia(28) }\end{array}$ & $\begin{array}{l}\text { Brazil } \\
2007\end{array}$ & $\begin{array}{c}\text { To assess the opinion of } \\
\text { women with pre eclampsia } \\
\text { on } \\
\text { nursing care received }\end{array}$ & $\begin{array}{l}\text { Qualitative study / } \\
12 \text { pregnant women } \\
\text { hospitalized with } \\
\text { pre eclampsia }\end{array}$ & - & $\begin{array}{l}\text { Nursing care was } \\
\text { limited itself to } \\
\text { BP measurement } \\
\text { and drug } \\
\text { administration }\end{array}$ \\
\hline $\begin{array}{l}\text { 17. Mulheres com } \\
\text { risco cardiovascular } \\
\text { após pré-eclâmpsia: há } \\
\text { seguimento no Sistema } \\
\text { Único de Saúde?(29) }\end{array}$ & $\begin{array}{l}\text { Brazil } \\
2004\end{array}$ & $\begin{array}{l}\text { To identify cardiovascular } \\
\text { risk factors in women five } \\
\text { years after delivery }\end{array}$ & $\begin{array}{l}\text { Descriptive study / } \\
130 \text { patients }\end{array}$ & - & $\begin{array}{c}\text { Greater frequency } \\
\text { of cardiovascular } \\
\text { disease in women } \\
\text { who have had pre } \\
\text { eclampsia }\end{array}$ \\
\hline
\end{tabular}

Based on these studies, we present a summary of each included study.

The study one included 104 pregnant women in two maternity wards of teaching hospitals. Women's BP was measured with two cuffs - suitable for arm circumference $(\mathrm{AC})$ and standard $(12 \mathrm{~cm})$, being held three measurements by cuff (six measures) with an interval of one minute between them, by the same researcher and with calibrated device. $\mathrm{AC}$ in the sample ranged from 20 to $38 \mathrm{~cm}$, and the appropriate cuff between 8 and $14 \mathrm{~cm}$. Small cuff for AC underestimated $\mathrm{BP}$ in $80 \%$ of cases and overestimated the $\mathrm{BP}$ by $5-8 \%$ among obese women $(\mathrm{AC}>32 \mathrm{~cm})$. The conventional cuff was adequate for only $13.4 \%$ of women. In lean women, it was underestimated, on average, $23 \mathrm{mmHg}$ SBP and $20 \mathrm{mmHg}$ DBP. The results indicated BP underestimation when measured with conventional cuff, with greater underestimation in lean women ${ }^{(13)}$.

In the second study, two BP readings were obtained, one quickly and the other with suitable lowering of mercury. The measurement was made by physicians, midwives and medical students. Assessing the pressure was evaluated as components established by the Protocol, namely: right arm descent rate $\leq 2 \mathrm{mmHg} / \mathrm{sec}$, bare skin, palpation of the brachial artery, positioning and correct cuff size, and feet on the floor. The results showed that the slow descent of the mercury is recommended; rapid cuff deflation underestimates BP; compliance benchmarking with the guideline was higher among specialists and midwives; and the most disturbing feature was the lack of mercury decrease in BP accuracy measurement ${ }^{(14)}$.

A series of measures adopted by a multidisciplinary team of a hospital to improve care for pregnant women at risk of developing pre-eclampsia is described in the third study. The strategy adopted by the service consisted of four guidelines: standardization of $\mathrm{BP}$ measurement methods; early drug therapy in 30 minutes when $\mathrm{BP} \geq 160 / 105 \mathrm{mmHg}$; evaluation of patients requiring antihypertensive medication, and after the diagnosis of pre-eclampsia, implementation of treatment in accordance with the PDIE method (Plan, Develop, Implement and Evaluate). The need for improvements to be implemented was observed, the monitoring of cases, including outpatient, and better management of assistance. The implications for nursing indicate the need for standardization of the BP measurement technique, identification of hypertensive crisis, urgent call for the multidisciplinary team, rapid drug treatment and review of work processes ${ }^{(15)}$.
A simulation of care in pre-eclampsia and eclampsia in the delivery room was proposed in the fourth study. They provided the following care in the pregnant woman admission: oral administration of nifedipine and information during labor (amniotommia; labor induction, anesthesia, blood pressure control and anesthetic evaluation). During eclampsia scenario, the care provided were: changing to left lateral recumbent position (LLRP); insertion of Guedel airway; oxygen therapy facility with facial mask; obtaining caliber venous access; measurement of $\mathrm{BP}$ and early magnesium sulfate protocol (four grams of 10 to 15 minutes and a continuous infusion to two grams/hour) ${ }^{(16)}$.

The results presented in the fifth study showed that, after training with the teamwork theory, there was a statistically significant decrease in the mean duration of techniques in the management of eclampsia and there also was a significant increase in the number of professionals who performed basic actions and additional assistance in eclampsia. The main care actions observed were: prescription, preparation and administration of the correct dose of magnesium sulfate, both attack and maintenance; call for help and the anesthetist; bed bedside removal for access to the airways; lowering the bed to reduce the risk of falls and maintenance of high bars when the resolution of the exacerbation; oxygen administration; measurement and monitoring of blood pressure, fetal heart rate, and establishing caliber venous access ${ }^{(17)}$.

Two groups received theoretical training and guidance for the management of hypertensive crisis in the sixth study. The first group received only theoretical instruction while the second group held, additionally, simulations. To perform a comparative assessment, a simulated call was performed for both groups, which was recorded and its images analyzed. There was better performance in the group that conducted the simulation in comparison to the group that received only theoretical training ${ }^{(18)}$.

The seventh study evaluated the skills of obstetric nurses in women cared with pre-eclampsia and/or eclampsia, after realistic training. For evaluation, we used a script with criteria of advanced skills in care that was applied before, immediately after and eight weeks after the training. The training method has shown significant benefits for professionals, particularly with regard to the early identification and adoption of appropriate nursing behaviors ${ }^{(19)}$.

In the eight study, the authors entitled the instrument to assess the symptoms of pre-eclampsia as Prenatal 
Symptom-Monitoring Scale among pregnant women with pre-eclampsia (PSMS). The content validation was performed by five judge experts in the area. The test was made through a retrospective, correlational and comparative study with 100 mothers with pre-eclampsia and gestational hypertension. It was concluded that the use of a scale to evaluate the symptoms (self-reported and based on the recall of last week) of pre-eclampsia during pregnancy, assists in the prediction and cause complications, allowing early implementation of nursing care ${ }^{(20)}$.

A graphic was developed to track the care of pregnant women with pre-eclampsia and eclampsia in the ninth study, which contains the data, namely: biodata, fetal heart rate, $\mathrm{BP}$, respiratory rate, proteinuria levels, number of seizures, level of consciousness, water balance, deep tendon reflexes, drug treatment (anti-hypertensives, magnesium sulfate and calcium gluconate), a summary of the woman hospital treatment and complications in the admission/ discharge, and treatment protocol toxicity by the use of sulfate magnesium and $\mathrm{BP}$ acute treatment. The results showed that most participants reported the graphic use as a great alternative for monitoring women, and emphasized its usefulness in improving care, specially, in monitoring and provision of evidence-based treatment. Perceived as challenges in graphic use, poor adherence to completion and high workload were highlighted. It was indicated that the graphics will be useful to provide better quality service and good quality documentation must be kept in the medical records or next to the bed ${ }^{(21)}$.

A case study of an 18 year old female with late-onset postpartum pre-eclampsia was described in the tenth study. It was reported to the nurse headache with progressive worsening and physical examination, presented BP 132/86 $\mathrm{mmHg}$ (greater than average presented in pregnancy $112 / 64 \mathrm{mmHg}$ ), mental confusion, proteinuria and hyperreflexia. The only care reported was seizure prophylaxis with magnesium sulfate. Four days later, the patient was discharged with fully reversed picture. The study also emphasized that breastfeeding is not contraindicated in case of magnesium sulfate use, from which reflections are present and conscious mother ${ }^{(22)}$.

The eleventh study mentioned the care of a woman at 36 weeks of gestation and diagnosis of eclampsia. The patient presented an episode of tonic-clonic seizure at home and was taken to hospital, with BP 200/90 $\mathrm{mmHg}$. She came to the emergency oriented, with headache complaints, nausea, blurred vision, sudden onset of swelling in the hands and face, and the physical examination showed tachycardia and normal fetal heartbeat. The main care performed were: establishment of caliber venous access; PLS positioning; oxygen therapy; collecting samples of blood and urine; magnesium sulfate administration in bollus with subsequent continuous infusion and hydralazine in bollus of 20 in 20 minutes according to the value of the BP; monitoring blood levels of magnesium; labor induction and maintenance of magnesium sulfate infusion for 24 hours postpartum ${ }^{(23)}$.

The case of a puerperal woman of 33 years who have undergone emergency cesarean section indicated by decompensation of pre-eclampsia, with subsequent admission to the Post-anesthesia care unit (PARU), was reported in the study 12. There were described physiological changes related to pregnancy, pathophysiology of pre-eclampsia and implications of PARU admission. The authors cited as nursing conducts: the administration of prescription drugs and blood products as well as the explanation of pathological changes that are happening throughout the care of women. It was concluded that prior knowledge of the pathophysiology of pre-eclampsia contributes to improvement in the nurse's performance ${ }^{(24)}$.

The thirteenth study described the case of a woman of 27 years, admitted to the emergency room eight days after delivery with complaints of headache and visual disturbances for one day. Immediate care were: BP measurement $(177 / 92 \mathrm{mmHg})$; urine collection and administration of medications for headache. After four hours, the patient reported improvement and was discharged. At home, she presented vomiting, headache and loss of consciousness followed by two seizures, returning to service, and then diagnosed with eclampsia. Care following the diagnosis were: call for help, diazepam and labetalol and magnesium sulfate loading dose was administered. After a minute of sulfate administration, the patient presented the third seizure, which led to continuous magnesium sulfate installation and blood collection for better diagnosis. The study found that emergency rooms nurses must recognize signs and symptoms of the diseases in question and use action protocols to prevent complications ${ }^{(25)}$.

The study 14 refers to the case of a pregnant woman who had abdominal pain and vaginal bleeding at the end of the third quarter. The obstetrician who monitored her sent her to the hospital for performing cardiotocography, installed by a nurse, who measured BP $(142 / 102 \mathrm{mmHg})$. It was later assessed by the physician and, as active bleeding was not observed and the fetus was in good condition, the woman was released with reevaluation request in one day. The next day, the obstetrician evaluated the pregnant woman in her office, and found $\mathrm{BP}=164 / 98 \mathrm{mmHg}$ and urine with proteinuria trace. She was sent to hospital and admitted by a second nurse who installed a fetal heart monitor, $\mathrm{BP}=163 / 97 \mathrm{mmHg}$ and massive proteinuria. As heart rate and fetal accelerations were present, the nurse administered fluids in bollus and requested her to remain in PLS. There was no admission time of registration, but the report says the obstetrician arrived at $1 \mathrm{pm}$, who held amniotomy and installed fetal scalp for continuous monitoring and, returned to his office. The nurse remained with the patient 10 to 15 minutes after the procedure. A few minutes after the departure, the patient observed a decrease of fetal heartbeat and pressed ringing. At $1: 20 \mathrm{pm}$ the nurse noted a falling rate and starts fetal resuscitation maneuvers. The duty physician assessed the patient and suspected placental abruption. At 1:43pm an emergency cesarean section was performed by the obstetrician. The infant was born with brain damage, and it was found detachment of $25 \%$ of the placenta. The case resulted in a lawsuit against the hospital and the nurses and in the first instance, the jury decided in favor of the defendants, but the case is still under evaluation in $\operatorname{court}^{(26)}$. 
Mortality cases that occurred in the Netherlands between 2000 and 2004 were assessed in the study 15. The standard of quality of care had presupposed the guidelines of the Dutch Society of Obstetrics and Gynecology. Of the 135 cases of deaths, 27 (20\%) women died as a result of hypertensive disorders. All women met the criteria for the diagnosis of preeclampsia, of which 16 (60\%) resulted in eclampsia. In 60\% of cases, prenatal care was performed by traditional midwives, and 96\% compliance was considered low-level or below required. As low quality examples, the authors cited late onset of prenatal care and lack of BP check in the first quarter. In $46 \%$ of cases, laboratory tests were not carried out for the detection of proteinuria, and in all of them, the risk factors for pre-eclampsia were present during pregnancy. There was delay in referral to treatment (15\%) and in hospital care, $41 \%$ did not make the relevant diagnostic tests, $85 \%$ had inadequately hypertension and $74 \%$ were misdiagnosis of mild pre-eclampsia when, in fact, they would be classified as severe cases. It was found that the low quality of care was present in almost all cases of maternal death resulting from hypertensive disorders ${ }^{(27)}$.

The study 16, a qualitative approach was developed with pregnant women hospitalized for pre-eclampsia. The reports pointed out that, in the view of these women, nursing care was limited to the BP measurement and administration of prescription drugs. These women also revealed that they felt satisfied with the care received (instrumental activities of nursing) and at the same time, dissatisfied with the relationship nurse/ patient. Women's expectations regarding nursing care refer to the humanization of care ${ }^{(28)}$.

In the study 17, a questionnaire was applied with 65 women who had pre-eclampsia and 65 normotensive women, five years after delivery. It was found that among those who had pre-eclampsia, $26 \%$ had a cardiovascular disease after the end of pregnancy, which showed a statistically significant difference. The authors also pointed out that these women did not perform follow-up and monitoring of clinical data. From the results, it was observed the need for an efficient system of reference and counter-reference and interdisciplinary care ${ }^{(29)}$.

\section{DISCUSSION}

The primary studies included in the first thematic category investigated the standardization of BP measurement technique, highlighting specific aspects for the early diagnosis and treatment of pre-eclampsia and/or eclampsia.

The pressure values obtained by measuring the BP, from the twentieth week of pregnancy, consists in one of the most important diagnostic criteria for case definition, and associated with the presence of proteinuria, elucidating the diagnosis of pre-eclampsia ${ }^{(3)}$. Thus, the measurement of BP is an important predictor of cases and should be properly assessed to avoid false positives or negatives.

The primary studies included in this review suggest as recommendations: BP measurement with appropriate cuff for $\mathrm{AC}^{(13)}$; slow speed deflation of the mercury column $(\leq 2$ $\mathrm{mmHg}$ ) to obtain more reliable and more precise results in the diagnosis ${ }^{(14)}$, early identification and drug treatment of hypertensive crisis through institutional protocols ${ }^{(15)}$.
The Association of Women's Health, Obstetric and Neonatal Nurses in the United States and Canada AWHONN released a clinical protocol focused on the diagnosis of hypertensive disorders. According to this protocol, BP should always be assessed in the sitting position with the arm at heart level. The pressure measured in PLS, as advocated in previous protocols can lead to a significant increase of $10-14 \mathrm{mmHg}$ in pressure levels, due to higher pressure in the left ventricle exerted by maternal position ${ }^{(29)}$. In addition, it points out that the value of diastolic blood pressure should be measured in the fifth phase of Korotkoff (disappearance of sound) and not in the fourth phase (muffling of the sound), as was reported in previous protocols. Finally, the protocol indicates ambulatory BP monitoring (ABPM) in 24 hours as the most effective technique and able to reduce measurement errors. This technique allows the evaluation of women in their routine and is a more sensitive predictor than clinical assessments, even in two measurements at different times. So it is up to the professionals to consider the cost-effective use for the diagnosis ${ }^{(30)}$.

Seeking best evidence and reducing measurement errors, the literature shows by the Royal College of Obstetricians and Gynaecologists protocol (RCOG), the following assistance actions: 1) BP measurement with appropriate and properly calibrated sphygmomanometer; 2) patient in sit position; 3) DBP should be considered as the value obtained in the fifth Korotkoff stage; 4) completion of at least two measurements and the value obtained must be the average of the two measures. Among other key recommendations, as evidenced in this study, it advocates the importance of BP measurement with appropriate cuff for arm circumference, with the slow deflation rate of descent established for $2-3 \mathrm{mmHg}$ per second and full deflate in 30 seconds $^{(31)}$.

Regarding the BP measurement technique, the last WHO publication is from 2005. Diastolic BP measurement is the most reliable indicator for the diagnosis of hypertensive disorders in pregnancy, since it is assessed through its measurement, peripheral vascular resistance and the obtained value does not vary with maternal emotional state. Therefore, the recommendations are: measurement of DBP in the fifth phase of Korotkoff; clamp cover at least three quarters of the circumference of the forearm and right arm; performing at least two measurements at intervals longer than six hours between measurements ${ }^{(6)}$.

Noteworthy that in a study on the current state of the art, looking as references the guidelines of the WHO, the American College of Obstetricians and Gynaecologists (ACOG), RCOG and publications from the journal The Lancet, it was determined that the measurement should be always carried out with the patient sitting and arm at heart level; the cuff should present appropriate dimensions; DBP should be measured in the fifth Korotkoff phase and, in any situation, manual sphygmomanometer with mercury column should be used, since it found an underestimation of $5-15 \mathrm{mmHg}$ in both SBP and DBP when the measurement was made with automatic measurement apparatus ${ }^{(32)}$. 
The primary studies included in the second catego$\mathrm{ry}^{(16-19)}$ investigated the training with simulation to face pre-eclampsia and eclampsia. Three studies used as strategy the realistic simulation for teaching and learning, characterized by a possibility of teaching that encompasses not only technical skills, but the crisis management, leadership, teamwork and clinical reasoning ${ }^{(33)}$. The results showed improvement in the performance of professionals in simulated environments ${ }^{(18)}$ and positive impacts on care $^{(17)}$ as the early identification of signs and symptoms of pregnant women with pre-eclampsia ${ }^{(19)}$, adoption of actions based on current protocols, more agility and performance of the multi-professional team in front of emergency situations ${ }^{(16)}$. The training of professionals involved in health care at different levels of attention brought gains to users and health professionals ${ }^{(19)}$.

In the third category - building instruments for standardization of care - studies 8 and 9 were included ${ }^{(20-21)}$. The results indicated that these instruments, which helped follow-ups and continuous monitoring of pregnant women with pre-eclampsia and/or eclampsia, should be used continuously by healthcare professionals, which, according to the evaluation of its proponents, improves the quality of care. It is worth mentioning here the value used by both instruments simultaneously, since in this way, relevant information from the patient (symptoms) and the professionals (objective records of implemented care) would be obtained.

The primary studies included in the fourth category highlighted aspects that standardize quality of care for early diagnosis, adequate treatment and prevention of maternal and fetal damage. The quality of care provided to pregnant women with pre-eclampsia and eclampsia reduces by $50 \%$ the risk of mortality ${ }^{(7)}$. For a high-quality care, the issues addressed in the previous three categories should work accordingly.

All actions of the multidisciplinary team should be governed by the needs of the mother and fetus. It is noteworthy, therefore, the importance of trained staff, able to recognize the signs and symptoms presented by the woman, to exclude differential diagnoses and then establish and implement the correct and necessary treatment in the setting of pre-eclampsia and/or eclampsia. The competence of the staff goes beyond the knowledge base, it is a set of skills and care that make effective work ${ }^{(34)}$.

The Joint Commission on Accreditation of Healthcare Organizations (JCAHO) published in 2010, the so called "Alert Sentinel Event", dedicated to the prevention of maternal death. The JCAHO highlights a study conducted in 2008, which evaluated individual causes of maternal deaths among one million and a half of births. According to the authors, the most common avoidable mistake when caring for patients with pre-eclampsia is the lack of attention to $\mathrm{BP}$ control and signs and symptoms of pulmonary edema. The authors also claim that the assessment of nursing and immediate intervention of all obstetric staff are fundamental to care for women with pre-eclampsia ${ }^{(35)}$.

Study 27 cites as examples of low quality in care, the lack of BP checks in the first quarter, which corroborates the study cited above ${ }^{(35)}$. Other low quality predictors were late onset of prenatal care, not early detection of proteinuria, delayed referral to hospital treatment and misdiagnosis ${ }^{(27)}$.

As limitations of the study: delimiting the time for the inclusion of studies is considered, which can lead to the exclusion of older studies, considered classics in the literature; the exclusion of other languages to include only studies in Portuguese, English and Spanish; and no possibility of homogenizing the boundaries of study designs for comparison of its results.

Nurses are the first professionals to have contact with pregnant women in obstetric emergency, so it is essential that nursing care is guided by current scientific evidence ${ }^{(1)}$. The collection of detailed data, careful physical examination and attention to blood pressure values and other preeclampsia signals; early detection of cases; the collection and monitoring of relevant laboratory tests, especially $24 \mathrm{~h}$ proteinuria and fetal assessment; promoting and encouraging the monitoring of prenatal consultations; the correct and rapid interventions, and call for help, requesting evaluation of anesthetist, administering oxygen, establishing caliber venous access and starting magnesium sulfate therapy; health education throughout the pregnancy and childbirth and hospital discharge are actions that if carried out, ensure excellence of care and the reduction of maternal and fetal morbidity and mortality in these patients ${ }^{(29,36)}$. Furthermore, we emphasize the need to target women about the importance of follow-ups for the prevention of late complications of hypertensive disorders, such as longterm monitoring of clinical data and adoption of healthy living habits ${ }^{(29)}$. Such actions were mentioned in studies 22 to 29 as essential for quality of nursing care in cases of pre-eclampsia and/or eclampsia.

\section{CONCLUSION}

The study enabled the synthesis of specific nursing care to women with pre-eclampsia and/or eclampsia, which can reduce complications and mortality rates. Nursing care described in this review covers mainly thorough physical examination, early detection of signs of pre-eclampsia/ eclampsia, monitoring laboratory tests, fetal assessment, professional training, including the need for continuing education, standardization of care from instruments, BP measurement with appropriate cuff for arm circumference, slow speed deflation of the mercury column $(\mathrm{mmHg} \leq 2)$, the need for standardization of the measurement technique of BP, early identification and treatment of hypertensive crisis through institutional protocols, as well as review of cases and work processes.

Creating and following care protocols guided by scientific evidence in daily clinical nursing practice can be helpful to guide the decision-making process and ensure the provision of quality and safe care.

We highlight the need for studies on the thematic subject of this review with methodological rigor, seeking to provide the nurse subsidies for nursing care. 
RESUMO

Objetivo: Analisar as evidências disponíveis na literatura sobre assistência de enfermagem às mulheres com pré-eclâmpsia e/ ou eclâmpsia. Método: Revisão integrativa cuja busca dos estudos primários foi realizada nas bases de dados PubMed, CINAHL, LILACS e SciELO. Resultados: Amostra foi composta por 17 estudos primários, publicados entre janeiro de 2000 e dezembro de 2014, agrupados em quatro categorias: padronização da técnica de mensuração da pressão arterial; treinamentos com simulação; instrumentos para padronização da assistência e qualidade da assistência As principais ações de enfermagem foram: exame físico, identificação precoce de sinais de pré-eclâmpsia/eclâmpsia, acompanhamento de exames laboratoriais, avaliação fetal, capacitação e treinamento dos profissionais. Identificou-se a necessidade de padronização do atendimento a partir de instrumentos e protocolos e da técnica de aferição da pressão arterial, identificação e tratamento precoces da crise hipertensiva mediante protocolos institucionais e revisão de casos e processos de trabalho. Conclusão: Mulheres com pré-eclâmpsia e/ou eclâmpsia exigem cuidados de enfermagem específicos, os quais devem ser pautados em protocolos de cuidados baseados em evidências científicas.

\section{DESCRITORES}

Pré-Eclâmpsia; Eclampsia; Cuidados de Enfermagem; Enfermagem Obstétrica; Revisão.

\section{RESUMEN}

Objetivo: Analizar las evidencias disponibles en la literatura acerca de la asistencia de enfermería a las mujeres con preeclampsia y/o eclampsia. Método: Revisión integradora, cuya búsqueda de los estudios primarios se llevó a cabo en las bases de datos PubMed, CINAHL, LILACS y SciELO. Resultados: La muestra estuvo compuesta de 17 estudios primarios, publicados entre enero de 2000 y diciembre de 2014, agrupados en cuatro categorías: estandarización de la técnica de mensuración de la presión arterial; entrenamientos con simulación; instrumentos para la estandarización de la asistencia y calidad de la asistencia. Las principales acciones de enfermería fueron: examen físico, identificación precoz de señales de preeclampsia/eclampsia, seguimiento de exámenes de laboratorio, evaluación fetal, capacitación y entrenamiento de los profesionales. Se identificó la necesidad de estandarización de la atención mediante instrumentos y protocolos y la técnica de verificación de la presión arterial,identificación y tratamiento precoces de la crisis hipertensiva mediante protocolos institucionales y revisión de casos y procesos laborales. Conclusión: Mujeres con preeclampsia e/o eclampsia demandan cuidados de enfermería específicos, los que deben pautarse en protocolos de cuidados basados en evidencias científicas.

\section{DESCRIPTORES}

Preeclampsia; Eclampsia; Atención de Enfermería; Enfermería Obstétrica; Revisión.

\section{REFERENCES}

1. World Health Organization (WHO). Cause specific mortality: regional estimateds for 2000- 2011. Geneva: WHO; 2012.

2. Say L, Chow D, Gemmill A, Funçalp O. Global causes of maternal death: a WHO Sistematic analysis. Lancet Global Health. 2014;2:e323-33.

3. World Health Organization (WHO). WHO Recommendations for prevention and treatment of pre-eclampsia and eclampsia. Geneva: WHO; 2011.

4. Brasil. Ministério da Saúde, Departamento de Informática do Sistema Único de Saúde (DATASUS). Óbitos de mulheres em idade fértil e óbitos maternos, 2011 [Internet]. Brasília; 2012 [citado 2013 jan.14] Disponível em: http://tabnet.datasus.gov.br/cgi/tabcgi.exe?sim/cnv/ mat10uf.def

5. Organização Mundial da Saúde (OMS). Recomendações da OMS para a prevenção e tratamento da pré-eclâmpsia e eclâmpsia. Brasília: OMS; 2013.

6. Organização Mundial da Saúde (OMS). Educação para uma Maternidade Segura. Módulos de educação em obstetrícia: eclâmpsia. Brasília: OMS; 2005

7. Duley L, Gulmezoglu AM, Henderson-Smart DJ, Chow D. Magnesium sulphate and other anticonvulsivants for women with pre-eclampsia. Cochrane Database Syst Rev. 2010;(11):CD000025.

8. Edward KL, Mills C. A hospital nursing research enhancement model. J Contin Educ Nurs. 2013;44(10):447-54.

9. Specht JK. Evidence based practice in long term care settings. J Korean Acad Nurs. 2013;43(2):145-53.

10. Galvão CM, Mendes KDS, Silveira RCCP. Revisão integrativa: método de revisão para sintetizar as evidências disponíveis na literatura. In: Brevidelli MM, Sertório SCM. Trabalho de conclusão de curso: guia prático para docentes e alunos da área da saúde. São Paulo: látrica; 2010. p.105-26.

11. Ursi ES, Galvão CM. Prevenção de lesões de pele no perioperatório: revisão integrativa da literatura. Rev Latino Am Enfermagem. 2006;14(1):124-31.

12. Polit DF, Beckn CT. Fundamentos de pesquisa em enfermagem: avaliação das evidências para a prática de enfermagem. $7^{a}$ ed. Porto Alegre: Artmed; 2011.

13. Oliveira SMJ, Arcuri EAM, Santos JL. Cuff width influence on blood pressure measurement during the pregnant-puerperal cycle. J AdvNurs. 2002;38(2):180-9.

14. Reinders LW, Mos CN, Thornton C, Ogle R, Markis A, Child A, Hennessy A. Time poor: rushing decreases the accuracy and reliability of blood pressure measurement technique in pregnancy. Hypertens Pregnancy. 2006;25(2):81-91.

15. Stephens-Hennessy BM, Senn L. Improving the outcomes of women with severe preeclampsia: exploring innovations used by an interprofessional team at a community hospital. JOGNN. 2014;43(S1):S52-3.

16. Martin T, McIntosh CA. Preeclampsia in the delivery suite: a simulation scenario. Simul Healthc. 2013;8(3):183-90.

17. Ellis D, Crofts JF, Hunt LP, Read M, Fox R, James M. Hospital, simulation center, and teamwork training for eclampsia management: a randomized controlled trial. Obstet Gynecol. 2008;111(3):723-31. 
18. Daniels K, Arafeh J, Clark A, Waller S, Druzin M, Chueh J. Prospective randomized trial of simulation versus didactic teaching for obstetrical emergencies. Simul Healthc. 2010;5(1):40-5.

19. Christian A, Krumwiede N. Simulation enhances self-efficacy in the management of preeclampsia and eclampsia in obstetrical staff nurses. Clin Simul Nurs. 2013;9(9):369-77.

20. Black KD, Morin KH. Development and testing of the Preeclampsia Prenatal Symptom - Monitoring Checklist (PPSMC). J Nurs Meas. 2014;22(1):14-28.

21. Ameh CA, Ekechi Cl, Tukur J. Monitoring severe pre-eclampsia and eclampsia treatment in resource poor countries: skilled birth attendant perception of a new treatment and monitoring chart (LIVKAN Chart). Matern Child Health J. 2012; 16(5):941-6.

22. Clark TP. Late-onset postpartum preeclampsia: a case study. Nurse Pract. 2014;39(7): 34-42.

23. Morgan E. Eclampsia. Nursing. 2002;32(3):104.

24. Noble KA. The critically ill obstetric patient. J Perianest Nurs. 2005;20(5):211-4.

25. White A. Emergency care of postpartum patients with preeclampsia and eclampsia. AENJ. 2006;28(3):248-57.

26. Delivering the verdict. Nursing. 2003;33(12):28.

27. Schutte JM, Schuitemaker NW, van Roosmalen J, Steegers EA, DucthMaternl Mortality Committee. Substandard care in maternal mortality due to hypertensive disease in pregnancy in the Netherlands. BJOG. 2008;115(6):732-6.

28. Cunha KJB, Oliveira JO, Nery IS. Assistência de enfermagem na opinião das mulheres com pré-eclâmpsia. Esc Anna Nery. 2007;11(2):25460.

29. Silva MLC, Galvão ACAA, Souza NL, Azevedo GD, Jerônimo SMB, Araújo ACPF. Mulheres com risco cardiovascular após pré-eclâmpsia: há seguimento no Sistema Único de Saúde? Rev Latino Am Enfermagem. 2014;22(1):93-9.

30. Peters RM, Flack JM. Hypertensive disorders of pregnancy. JOGNN. 2004;33(2): 209-20.

31. Crafter H, Milne F. An early system for pre-eclampsia. Pract Midwife. 2005;8(9):17-20.

32. Barra S, Cachulo MC, Providência R, Leitão-Marques A. Hipertensão arterial na grávida, o atual estado da arte. Rev Port Cardiol. 2012;31:425-32.

33. Brandão FS, Collares CF, Marin HF. A simulação realística como ferramenta educacional para estudantes de medicina. Sci Med [Internet]. 2014 [citado 2015 abr. 22];24(2) Disponivel em: http://revistaseletronicas.pucrs.br/ojs/index.php/scientiamedica/article/ viewFile/16189/11485

34. Collins A, Sutton RS, Handley M, Oliver D, Patterson L, Tew NL, et al. An exemplar of team competence. Crit Care Nurse. 2007;27(2):142-4.

35. Clark SL, Belfort MA, Dildy GA, Herbst MA, Meyers JA, Hankins GD. Maternal death in the 21st century: causes, prevention, and relationship to cesarean delivery. Am J Obstet Gynecol. 2008;1993:e1-36e5.

36. Townsend NS, Drummond SB. Preeclampsia: pathophysiology and implications for care. J. Perinat Neonat Nurs. 2011;25(3):245-52. 